\title{
Reflections on Leadership Styles from Higher Education in India
}

\author{
Manodip Ray Chaudhuri ${ }^{1, *}$, Juha Kettunen ${ }^{2}$, Partha Naskar ${ }^{3}$ \\ ${ }^{1}$ Amity Business School, Amity University, Kolkata, India \\ ${ }^{2}$ Executive Committee of EAIR, Turku University of Applied Sciences, Finland \\ ${ }^{3}$ Department of Commerce and Management, West Bengal State University Kolkata, India
}

Copyright $(\mathcal{C} 2015$ by authors, all rights reserved. Authors agree that this article remains permanently open access under the terms of the Creative Commons Attribution License 4.0 International License

\begin{abstract}
The surfacing of the concept of leadership dates back to the ancient days of war and inhabitation. Over time, leadership evolved to accomplish goals. The guiding thoughts of a mission and vision are the essence of new millennium leadership. The modern business companies aim for continuous identification and understanding about the wide array of the global perspectives of leadership. This paper discusses organisational leadership, leaders' traits and habits; leadership competencies to manage workplace crises; transformational and servant leadership; the importance of towards transformational leadership; and the unification of leadership and business culture. The paper concludes with an appeal for global leadership that builds sustainability in an ever-changing global business environment.
\end{abstract}

Keywords Leadership, Capabilities, Transformational, Servant, Organisation, Higher Education

\section{Introduction}

Business leaders emphasise the necessity of leadership in an increasingly turbulent and complex organisational environment. The role of an organiser has shifted from being a 'leader' to 'leading' the organisational hemisphere. Leadership is the role which an individual occupies at a given time in a given group [11]. The accomplishment of organisational goals is illuminated by the visionary leader. The power supplemented by authority has been replaced by guidance, coordination and integration in resolving organisational issues. The organisational success is led by the leader in confronting the hindrances with confidence coupled with a deeper sense of belongingness, foresightedness and creativity. Leadership is the ability to attract willing followers and to effect change [18].

The purpose of this paper is to cast light on organisational crises and leadership capabilities, leading organisations through transformational and servant leadership, urgency for transformational leaders for organisational prosperity and anchoring organisations with global leadership. The empirical part of the paper describes transformational and servant leadership in Indian higher education. The paper ends by reiterating the value of global leadership for organisational growth and prosperity.

The crisis is an inevitable phenomenon in the context global leadership behaviour. The leadership styles create the central theme in the story of leadership success and leadership failure. The uncertainty in the leadership emerges as the major concern in organisations. The traits and the behavioural attributes of leadership behaviour of successful crisis leaders may be comprehended as the perception of the reality, the comprehensive approach to tasks and functions, multiple alternatives for the organisation building, decisiveness, collaboration at work, calm and positive composure, risk taking attitude, rule-centred behaviour and accepting criticism concerned with mistakes [21].

Common leadership capabilities for crises management can be understood in terms of typical competencies such as initiating groundwork, management of loss, revival of trade and enhancement of knowledge. Such competencies of a leader go a long way in addressing the visible crises in the organisational hemisphere: the creation of faith, the innovative outlook, identifying vulnerability, speedy decision making and introduction of new learning [20].

Thus there is a positive relationship between leadership capabilities and crises management in the global context towards building an optimistic change in the real sense of the term. To combat the storms of organisational catastrophe a leader should adhere to the directives of crisis management in the sphere of over-viewing the actual situation with prompt action compounded through management of expectations and assuming control action supplemented by a liberal outlook. A leader's perspective is often measured during catastrophic conditions to keep a distinguishing mark of insight, vision and ability amidst the underlying waves of divergent upheaval for organisational survival and sustenance [19]. 


\section{Leadership}

Leadership is fundamentally understood as an approach or methodology by which an individual influences a group of individuals to attain some common objective or goal. The goal is accomplished by mutual cooperation and cohesive behavior. Professionally speaking, a leader infuses a sense of positivity and directs others to reach specific goals and objectives.

Psychologists have arrived at various theoretical undertones to explain leadership traits. Management literature explains leadership in terms of typical characteristics viz.: intelligence, empathetic, extraversion, adjustment, openness to experience, decision maker, self-efficacy, conscientiousness and some such.

A leader is someone who stands not only for his cause but takes responsibility for the cause of others as well. He is a motivator for others in a team. It needs to be noted that there is a comprehensible distinction between a boss and a leader. A leader is motivation for others and inspires individuals to go high in work settings, whereas a boss merely supervises over his subordinates. Power naturally comes to a true leader as he is always accepted by his followers, but that power is generally never a contrivance of a leader. If one tries to control conditions and situations with the element of power, as a means to rule, it turns out to be very typically authoritarian or even suppressive in and deed [6].

Leadership, as a feature, can be understood as an individual's behavior, embedded deep into ones conduct. A leader essentially reflects positive attitude and a high degree of self esteem. His approach may be aggressive but he is not hard or pushy in his style. He is a person, who fundamentally is very self-analytical and scrutinizes and analyses his plans and actions always. It is the confidence and trust of subordinates that make a supervisor a true leader [7].

\section{Essentials of Transformational and Servant Leadership}

A common paradigm is often cited between transformation and service to blend the shades of human nature which enrich the lives of individuals for building better organisations. The path of effective leadership with visionary views supplemented by the intellectual stimulation amidst the waves of transformational leadership behaviour strengthens the relationships and trust between the leader and followers [25].Transformational leadership is the product of past experience to future course of action through innovative ideas, views and intellect. Servant leadership encompasses collective force, power, collaboration and the empowerment of followers.

The process of renovation takes the form of transformational leadership through the phases of transition substituting older views of leader-centred ideals to the innovative views designed with the varied dimensions of leadership theory[4]; [7]; [9]; [17]. The new avenues of transformational leadership step forward with fresh considerations within Watters' [27] four-dimensional construct that includes:

- idealised authority

- inspirational motivation

- intellectual stimulation

- individualised contemplation

In the arena of idealised influence, transformational leaders are internally driven visionaries who look beyond technical competencies and political exchange. A transformational leader focuses on vision realisation and acts within the frame of the moral system gaining the strength of control in the spectrum of values, behavioural oneness and self-generating ideals. The qualitative aspect of a transformational leader can be visualised in the context of adaptability and realign their perspective amidst ever-changing environment. The storehouse of strength is the epicentre of potential of transformational leaders paving the way for the future followers in the organisational hemisphere.

The waves of encouragement join with inspirational motivation where a transformational leader takes part in the organisational makeover through actions, modelling, decision-making and personal attitude all revitalising for a refresh organisational culture. The hymn of inspiration enlightens the true spirit within the employees as they constitute the realistic foundation of freedom, fruitfulness and fraternity.

The wideness of intellect touches the feat of attainment where the transformational leader encourages a follower's innovation and creativity and steps forward to shoulder risks and uncertainties for organisational benefit in the long run. A universal mind-set is crafted by the transformational leader to participate, promote and promise for the sake of organisational upliftment united within the wings of rights, responsibilities and reward. The decision making mechanism runs through all the layers of the organisational hierarchy where all the members possess the right to participate.

The significance of individualised consideration takes part in individual endeavour through assimilation of employees' cultural perceptions, shared values, beliefs and norms. The transformational leader attempts to recreate an understanding between employee perception, performance and productivity.

The proponents of servant leadership could not penetrate deep into the levels of the organisational surface with the constraints as the field is not broad based. Servant leadership contemplates on greater mutual power and influence, emphasises collective and collaborative follower participation and promotes follower learning and empowerment. The source behind servant leadership has its root in the theory of complexity and chaos. The wheels of servant leadership encircle decentralisation, the differentiation of tasks, collaboration, flexibility and adaptability of structures and processes, participation and autonomy.

The images of servant leadership can be visualised within 
the perspectives of individual, cultural, decision-making and organisational change [2]; [12]. Servant leaders are signified by their traditional component. Servant leaders believe in and selflessly serve their people. The goodness of a follower is the distinctive feature of the servant leaders which postulates the significance of a good leader.

The phases of growth, learning, encouragement and affirmation provide the cultural perspective of the servant leaders. The knot of well-built relationships complemented with collaboration, value opinion, openness, willingness to learn, development of integrity and trust all contributes the cultural magnitude of servant leaders. Regardless of their own concern, servant leaders step forward to contribute to the cultural enhancement and wellbeing of people [22]; [23].

Visualising the decision making domain where a true servant leader takes decision focusing on renovating their followers to elevate to the level of greatness at the cost of sacrificing their own acknowledgment and recognition. The trueness of servant leaders chases the progression to pursue their follower's finest interest, to create a psychological and social platform with their followers and to expand and extend the tangible and intangible relationships with the followers.

The assessments of the effectiveness of a servant leader need to be initiated from the perspective of an organisational changeover. The multi-angled phenomenon of efficacy comprising skill, future foresight, the visionary goal all attributes of servant leaders conglomerated during the organisational transformational process promotes an add on value in developing an exemplary organisational culture. The servant leaders strive amidst the phases of organisational change shares status, vision and power with the aim of supporting the followers to adapt and focus on the advent of new ethnicity at the organisational hemisphere[24]; [28].

Figure 1 depicts the features underlying transformational and servant leadership styles. The spotlight on the prime objective of the transformational leader vests on the attainment of the organisational goal and servant leaders follow the principles of self-enhancement and employee promotion [1]; [26].

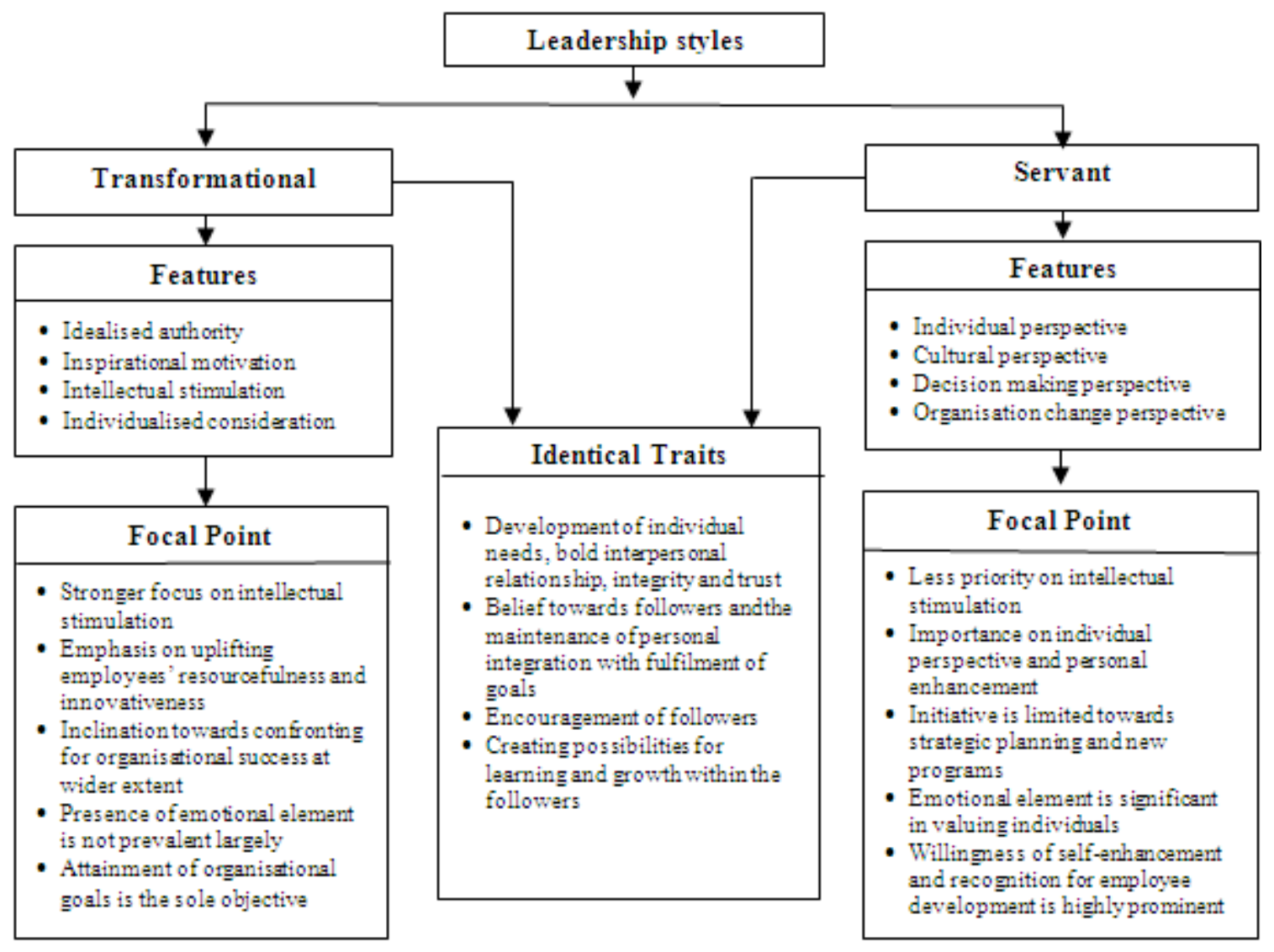

Adapted from TOJQIH Vol. 2, Issue 4, Sakarya, Turkey

Figure 1. Transformational and Servant leadership styles - Features and Focus 


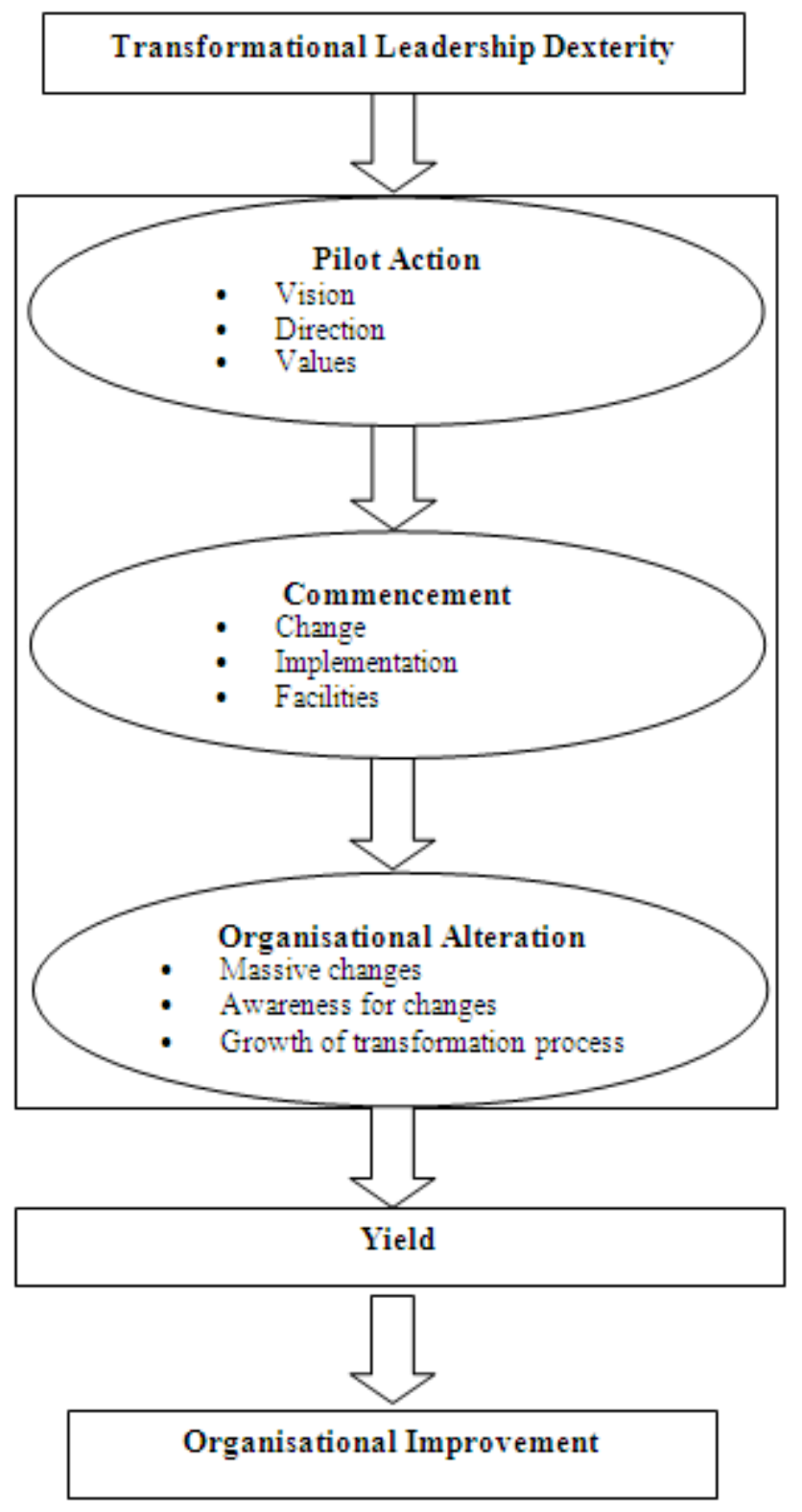

Adapted from TOJQIH Vol. 2, Issue 4, Sakarya, Turkey

Figure 2. The Path towards Organizational Transformational

\section{Need for Transformational Leader for Organisational Prosperity}

Figure 2 identifies the fundamental aspects of transformational leadership showing the path towards organizational transformation. The requirement of basic ingredients in the creation of an ideal transformational leader is rooted within skill and behavioural characteristics. In today's organisation, development can occur with the changing waves and positive vibes of transformational leaders disseminated throughout various organisational cells in the form of individuals, groups and teams. The three core elements of transformational leadership can be determined with recognition, creation and institutionalisation whereby assimilation between organisation development and transformational leadership is viewed with a self-renewal perspective and organisational effectiveness[6].

Strategic management involves planning for the long term with clearly articulated mission, direction and values. Strategic management helps the organisation to lead their personnel towards the fulfilment of objectives. The questions of who is involved in the strategy process, how the process is taking place and how to motivate personnel receive different answers in each organisation. The involvement of management, personnel and other stakeholders is important in the process. The strategy process creates commitment to achieve the strategic objectives. The communication and implementation of the strategic plan are typically much more important than the plain strategy document [14]; [15]; [16].

The need for transformational leaders can be visualised with vision, personified with personality and strengthened with strategies. The makeover component of transformational leaders truly inspires the followers to change their perceptions, personality and performance through passion, morale and motivation propounded by the reformatory leaders. Transformational leadership is embedded in three core concepts of leading, initiating and organisational makeover. The leader behaviour in this pattern of leadership interacts with the organisation as an input mechanism towards creating the aptand timely output towards organisational development. This output refers to the end results and outcomes of an effective transformational leadership skill set geared towards overall organisational prosperity as time passes[13].

\section{Thoughts from Leaders in Higher Education in India}

Leadership can be continuously improved following Deming's Plan-Do-Check-Act sequence [8]. At the first stake, the objectives of leadership are planned. The plans are then implemented. The third stage is the evaluation of the achievement of objectives and the conformance to processes. Based on the results of the evaluation leadership can be improved. Once leadership has been amended, improved results can be expected.

Table 1 depicts the empirical evidence on transformational leadership in Indian higher education. A random sample of 23 leaders in higher education institutions in Eastern India shared their view of transformational and servant leadership. An open-ended discussion generated the following responses describing the elements of transformational leadership. The table supports the evidence that transformational leadership is extremely relevant in higher education. Development steps can be taken in leadership using these results.

Table 2 depicts the empirical evidence of servant leadership in Indian higher education. The summary of responses shows that many elements of servant leadership are relevant supporting the fact that both leadership styles are relevant and needed in higher education institutions. The 
leadership styles must be balanced in each organisation to find an appropriate combination of leaders to achieve the desired objectives.

Table 1. Empirical reflections on transformational leadership

\begin{tabular}{|c|c|}
\hline $\begin{array}{c}\text { Elements of } \\
\text { transformational leadership }\end{array}$ & Summary of responses \\
\hline Idealised authority & Extremely significant for top leaders \\
\hline Inspirational motivation & $\begin{array}{l}\text { Relevant in day-to-day work } \\
\text { processes }\end{array}$ \\
\hline Intellectual stimulation & Relevant to nurturing novelty \\
\hline Individualised consideration & $\begin{array}{c}\text { Significant for building effective } \\
\text { teams }\end{array}$ \\
\hline Being resourceful & $\begin{array}{c}\text { Effective for craftinga learning } \\
\text { organisation }\end{array}$ \\
\hline $\begin{array}{l}\text { Being innovative and } \\
\text { creative }\end{array}$ & $\begin{array}{c}\text { Extremely effective to build on } \\
\text { sustainability }\end{array}$ \\
\hline $\begin{array}{c}\text { Confrontation for } \\
\text { organisational success }\end{array}$ & Significant in brainstorming meets \\
\hline Empathy and emotion & $\begin{array}{c}\text { Effective to create organisational } \\
\text { citizenship }\end{array}$ \\
\hline $\begin{array}{l}\text { Leadership for cultural } \\
\text { change }\end{array}$ & $\begin{array}{l}\text { Helps in building on self-efficacy and } \\
\text { adaptability }\end{array}$ \\
\hline Ability to attract followers & $\begin{array}{l}\text { Significant in group dynamics and } \\
\text { cohesion }\end{array}$ \\
\hline Crises handler & Relevant in generating trust on leaders \\
\hline
\end{tabular}

Taken from TOJQIH Vol. 2, Issue 4, Sakarya, Turkey

Table 2. Empirical reflections on servant leadership

\begin{tabular}{|c|c|}
\hline Elements of servant leadership & Summary of responses \\
\hline Individual perspective & $\begin{array}{c}\text { Significant for situational } \\
\text { analysis }\end{array}$ \\
\hline Cultural orientation & $\begin{array}{c}\text { Helps in adhering to cultural } \\
\text { norms }\end{array}$ \\
\hline Ability to decide & $\begin{array}{c}\text { Significant in fostering } \\
\text { sustainability }\end{array}$ \\
\hline Clarity in organisational change & Effective in embracing novelty \\
\hline Goal of personal enhancement & $\begin{array}{c}\text { Effective for creating a learning } \\
\text { organisation }\end{array}$ \\
\hline Belief in strategic planning & $\begin{array}{c}\text { Extremely effective to build on } \\
\text { sustainability }\end{array}$ \\
\hline Ability to value individuals & Significant in teambuilding \\
\hline $\begin{array}{c}\text { Recognition of employee } \\
\text { development }\end{array}$ & $\begin{array}{c}\text { Effective to create superior } \\
\text { performers }\end{array}$ \\
\hline
\end{tabular}

Taken from TOJQIH Vol. 2, Issue 4, Sakarya, Turkey

Table 1 and Table 2 depict what practitioners in the field of higher education think about the core elements of both transformational and servant leadership. Both approaches build on organisational success; however, it remains in the demands of the situation being handled and the profile of the leadership position that ultimately dictates a choice between transformational and servant leadership.

\section{Discussion}

Amidst the ever-changing phases of the global environment, the urge for leadership competencies confronts multifaceted complications worldwide. The leading assignment designed with interactions and fabricated by the cultural interconnectedness encircles the prospects and dynamics of leadership. The leaders of the new millennium have laid the cornerstone of global leadership development with the combination of the trio level of intelligence patterns. The magnitude of leadership expertise compounded by diverse complexities results in increasing inconsistency in leadership behaviour among the twenty-first century leaders[5].

The varied attributes of way of life in the form of language, race, gender, ethnicity, experience, knowledge and other allied elements characterises the effectiveness of future leaders across the globe. The progression of leadership development equipped with creative coaching, methodical mentoring, systematised schedules and potential personality assignments lead the way to reach the elevation of success and sustenance. The scale of valiant leadership confidence engulfed with diversities and differences can truly be termed as the global leadership footprint in the organisational landscape.

Adapting a global mind-set with the inherent influential ability to think, appreciate, develop, share and synthesise the framework of international standards, all have driven global leadership competencies across the world-wide diversity. The prominent clusters or anchors in identifying global leadership skills viz. diversity strategies, diversity tools, diversity competence, diversity dimensions and cultural bias and real life situations cumulatively constitute the vital fundamentals of leadership effectiveness in a global framework. Crossing the constraints of time, overcoming the limitations of fund, shaping the uncurbed into formations through the journey filled with inadequacy, insufficiency and uncertainty, leaders reinvent the ways and means which postulates the best chance of maximising returns to strengthening global leadership potential[3].

\section{Conclusions}

Leadership has distinct capabilities and competencies, manages crises effectively, upholds typical traits like transformational and servant leadership, handholds the organisation towards long run prosperity, generates profitable end-results for the business and unifies complexities towards building strong organisations in the real sense of the term.

It is the universal leadership foresight which postulates all the facets of vibrant leadership terrain to identify, welcome and admire for the acceleration of worldwide leadership experience on a global stage. Following the words of Peter F.Druker, "management is doing things right; leadership is doing the right things". A true manager is always born from a true leader, whether it is crisis or smooth sailing in the workplace.

Leadership is the most crucial for organisational operations and it can be evaluated and developed using the principle of continuous improvement in quality assurance. The empirical results support the argument that transformational leadership is necessary in higher education 
for organisational development and prosperity. It must be balanced with servant leadership, which contemplates greater mutual power and influence. Both leadership styles build on organisational success, but their balance remains in the demands of the situation being handled.

\section{Notes}

An earlier version of this paper was presented at the International Conference on Quality in Higher Education $I C Q H 2014$ during December 3 - 5, 2014 at Sakarya University in Sakarya, Turkey and the paper was also published in International Conference on Quality in Higher Education -ICQH 2014 Proceedings Book, edited by Prof. Dr. Aytekin İŞMAN and Assoc. Prof. Dr. Ahmet ESKICUMALI of Sakarya University, Turkey, published from Sakarya University, Sakarya, Turkey, Edition 2014. The earlier version of the paper has also been published in The Online Journal of Quality in Higher Education (TOJQIH), Oct. 2015, vol. 2, issue 4, Sakarya University, Sakarya, Turkey. This current version is essentially a reprint publication, with minor incorporations and editing, on request from Horizon Research Publishing, USA.

\section{REFERENCES}

[1] Avolio, B. J., \& Yammarino, F. J. (2002). Transformational and charismatic leadership: The road ahead. Amsterdam: JAI - Elsevier Science.

[2] Banutu-Gomez, M. B. (2004). Great leaders teach exemplary followership and serve as servant leaders. Journal of American Academy of Business, 4(1/2), 143-150.

[3] Bartlett, C. A., \&Ghoshal, S. (1992). What is a global manager? Harvard Business Review, 70(5), 124-132.

[4] Bauers Joslin, S. J. (1996). Predicting transformational and transactional leadership behaviors from individual thinking and behaving preferences (Unpublished doctoral dissertation).The University of Nebraska-Lincoln, United States.

[5] Begley, T. M., \& Boyd, D. P. (2003). The need for a corporate global mind-set.MIT Sloan Management Review, 44(2), 25-32.

[6] Bennis, W. (2006). Why lead? Leadership Excellence, 23(10), 4-5.

[7] Burns, J. M. (1978). Leadership. New York, NY: Harper \& Row.

[8] Deming, W.E. (1986).Out of the crisis. Cambridge, MA: MIT Center for Advanced Engineering Study.

[9] Drew, S., \& Coulson-Thomas, C. (1996). Transformation through teamwork: The path to the new organization. Management Decision, 34(1), 7-17.

[10] Drucker, P. F. (2001). The essential Drucker: Management, the individual and society. New York, NY: Harper Collins.

[11] Gouldner, A. (1950). Studies in leadership. New York, NY: Harper \& Row.

[12] Hamilton, F., \& Bean, C. J. (2005). The importance of context, beliefs, and values in leadership development.. Business Ethics: A European Review, 14(4), 336-347.

[13] Jung, D. I., Chow, C., \& Wu, A. (2003). The role of transformational leadership is enhancing organisational innovation: Hypotheses and some preliminary findings. The Leadership Quarterly, 14, 525-544.

[14] Kettunen, J. (2006). Strategic planning of regional development in higher education. Baltic Journal of Management, 1(3), 259-269.

[15] Kettunen, J. (2008). A conceptual framework to help evaluate the quality of institutional performance. Quality Assurance in Education, 16(4), 322-332.

[16] Kettunen, J., \& Chaudhuri, M. R. (2011). Knowledge management to promote organizational change in India, In M. Al-Shammari (Ed.), Knowledge management in emerging economies: Social, organizational and cultural implementation (pp. 308-324). Hershey, PA, USA: IGI Global.

[17] Lea, D. (2004). The imperfect nature of corporate responsibilities to stakeholders. Business Ethics Quarterly, 14(2), 201-217.

[18] Mamoria, C. B., \& Gankar, S. V. (2007). Personnel management. Mumbai: Himalaya Publishing House.

[19] Nurdan, Ö. (2003). Effects of transformational leadership on empowerment and team effectiveness. .Leadership and Organization Development Journal, 24(6), 335-344.

[20] Pearson, C. M., \& Clair, J. A. (1998). Reframing crisis management. Academy of Management Review, 23(1), 59-76.

[21] Pearson, C. M., \&Mitroff, I. I. (1993). From crisis prone to crisis prepares: A framework for crisis management. Academy of Management Executive, 7(1), 48-59.

[22] Pepper, A. (2003). Leading professionals: A science, a philosophy and a way of working. Journal of Change Management, 3(4), 349-360.

[23] Ray Chaudhuri, M., Kettunen J. and Naskar, P. (2014) "Transformational and Servant Leadership: Evidence from Indian Higher Education" in International Conference on Quality in Higher Education - ICQH 2014 Proceedings Book, edited by Prof. Dr. Aytekin İSMAN and Assoc. Prof. Dr. Ahmet ESKICUMALI of Sakarya University, Turkey, published from Sakarya University, Sakarya, Turkey, Edition 2014.

[24] Ray Chaudhuri, M., Kettunen J. and Naskar, P. (2015) "Transformational and Servant Leadership: Evidence from Indian Higher Education" in The Online Journal of Quality in Higher Education (TOJQIH) Vol. 2, Issue 4 from Sakarya University, Sakarya, Turkey in October, 2015

[25] Rowe, R. (2003). Leaders as servants. New Zealand Management, 50(1), 24-25.

[26] Salopek, J. J. (2004). Engaging mind, body and spirit at work. $T+D, 58(11), 17-19$. 
[27] Segil, L., Goldsmith, M., \& Belasco, J. (2003). Partnering: The new face of leadership. New York, NY: AMACOM.

[28] Washington, R. R. (2007). Empirical relationships between theories of of servant, transformational, and transactional leadership. Academy of Management Proceedings, 1-6. Retrieved December 13, 2007, from Business Source

\section{Complete database.}

[29] Watters, K. (2006). Thinking about leadership.Adults Learning, 18(3), 18-19.

[30] Whetstone, J. T. (2002). Personalism and moral leadership: The servant leader with a transforming vision. Business Ethics: A European Review, 11(4), 385-392. 